\title{
Bioaugmentasi Benzena Tanah Tercemar Hidrokarbon yang Dibiodegradasi secara in vitro dengan Menggunakan Bacillus Sp. Strain U41 dan U44
}

\section{Bioaugmentation of in vitro Benzene Hydrocarbon Biodegradation on Contaminated Soil by Bacillus Sp. Strain U41 and U44}

\author{
Agus Irianto $^{1 *}$ Oedjiono $^{1}$, Agus Riyanto $^{1} \&$ M. Syamsul Komar ${ }^{1}$ \\ ${ }^{1}$ Fakultas Biologi Universitas Jenderal Soedirman, Purwokerto 53123, *korespondensi
}

\begin{abstract}
Soil pollution by substances such as benzene can cause serious problems such as aquifer contamination and reduction of the biodiversity of organisms. A number of microorganisms are capable to degrade such substances naturally. However, introduction of any other microorganisms and or nutrient (bioaugmentation) are necessary in order to improve the biodegradation rate. This study examined the effect of introducing promising local strains of Bacillus namely U41 and U44, and urea addition at concentration $0.25 \% \mathrm{w} / \mathrm{v}$. The parameter measured was benzene, $\mathrm{pH}$, microbial number, and $\mathrm{CO}_{2}$. The best result was revealed from bioaugmentation of mixture of $U 41$ and $U 44$. However, that result was not significantly difference with the use of single either strain U41 or U44, respectively.
\end{abstract}

Key words: Bacillus, bioaugmentation, biodegradation, soil, benzene

Diterima: 3 April 2003, disetujui: 10 September 2003

\section{Pendahuluan}

Senyawa aromatik merupakan senyawa rekalsitran yang sulit diuraikan oleh mikroba (Atlas \& Bartha, 1987). Salah satu senyawa aromatik penyusun minyak bumi yaitu benzena yang memiliki cincin aromatik tunggal. Benzena dapat bersifat toksik terhadap lingkungan antara lain mempengaruhi metabolisma bakteri heterotrofik pada perairan dan sedimen, tetapi sifat toksik tersebut tidak sebesar hidrokarbon aromatik yang digolongkan sebagai PAH (polynuclear aromatic hydrocarbon), seperti naftalen dan fenantren (Capone \& Bauer, 1992). Sifat toksik diminimalisasi melalui pemecahan cincin aromatik dengan memanfaatkan enzim mikroba.

Sejumlah mikroba diketahui mampu mendegradasi senyawa hidrokarbon aromatik. Bakteri yang diketahui mampu mendegradasi senyawa hidrokarbon aromatik antara lain:
Pseudomonas, Arthrobacter, Alcaligenes, Brevibacterium, Brevibacillus, dan Bacillus (Balba et al., 1998; Grishchenkov et al., 2000; Chen et al., 2001). Spesies-spesies Bacillus yang mampu mendegradasi komponen minyak bumi berupa senyawa aromatik, antara lain: Bacillus macerans, B. mycoides, $B$. megaterium, $B$. subtilis, $B$. pumilus, $B$. thermoleovorans, $B$. gordonae, dan $B$. benzoevorans (Sharpley, 1966; Pichinoty et al., 1986; Zarilla \& Perry, 1987).

Pencemaran hidrokarbon dapat berlangsung pada air, tanah, dan udara. Pencemaran itu berasal dari industri perminyakan hulu, hilir dan distribusinya. Pada sejumlah kasus, pencemaran yang terjadi sangat berat hingga mencemari lapisan aquifer air tanah atau area yang luas di darat maupun di perairan.

Salah satu usaha mengatasi akibat pencemaran yang populer yaitu cara biologis yang dikenal sebagai bioremediasi. Efektivitas bioremediasi sangat ditentukan oleh faktor- 
faktor tertentu seperti: konsentrasi mikroba pendegradasi cemaran, konsentrasi cemaran, suhu, $\mathrm{pH}$ optimum, ketersediaan oksigen, dan nutrien (Bouwer, 1992).

Penelitian secara in vitro menggunakan Bacillus strain lokal telah dilakukan untuk mengetahui kemampuannya dalam mendegradasi toluen (Irianto \& Komar, 2000). Penelitian yang dilakukan menunjukkan bahwa penambahan dua strain Bacillus secara bersama-sama dan dengan penambahan $0,25 \%$ urea, mampu mennurunkan kadar toluena dari 510,07 ppm menjadi 15,03 ppm atau penurunan 97,05\% dalam masa tiga minggu. Suplementasi nutrien berupa sumber $\mathrm{N}$, misalnya urea atau amonia, dapat meningkatkan kemampuan mikroba dalam mendegradasi hidrokarbon (Sabarni, 1995; Irianto \& Komar, 2000).

\section{Metode Penelitian}

Isolat Bacillus U41 dan U44 yang diisolasi dari Taman Nasional Ujungkulon diremajakan pada medium agar nutrien (NA Oxoid). Selanjutnya ditumbuhkan pada medium kaldu nutrien (NB-Oxoid) dan diinkubasi 2 x 24 jam. Mikroba yang tumbuh pada kaldu nutrien dihitung populasinya secara langsung menggunakan hemositometer. Jika jumlah sel telah mencapai $10^{7} \mathrm{sel} / \mathrm{ml}$ maka kultur dapat digunakan sebagai inokulum, jika kurang maka harus dipekatkan dengan sentrifugasi dan membuang sebagian cairan aliquot, dan jika berlebih harus diencerkan.

Disiapkan ember plastik volume 5 liter sesuai kebutuhan (48 buah) masing-masing diisi dengan tanah yang tercemar minyak bumi sebanyak $500 \mathrm{~g}$, selanjutnya diisi dengan akuades steril sebanyak $500 \mathrm{ml}$ dan diaduk rata. Inokulum yang sudah siap diinokulasikan ke masing-masing ember plastik sebanyak 50 $\mathrm{ml}$ dan ditambahkan urea $0,25 \%$ berat/volume. Untuk penggunaan kultur campuran, maka penambahan dilakukan seimbang dengan menambahkan $25 \mathrm{ml}$ dari masing-masing suspensi Bacillus (U41 dan U44). Adapun kontrol dilakukan dengan penambahan $50 \mathrm{ml}$ akuades steril. Perlakuan tersebut masingmasing dengan tiga ulangan dan diamati pada awal penelitian, akhir minggu ke-1, akhir minggu ke-2, dan akhir minggu ke-3.

Beberapa peubah yang diamati yaitu kadar benzena sisa dengan GC (Noegrohati, 1983), $\mathrm{CO}_{2}$ bebas (APHA, 1985), jumlah sel mikroba menggunakan agar cawan atau TPC (Total Plate Count) (Joetono dkk., 1980), dan nilai $\mathrm{pH}$ (dengan $\mathrm{pH}$ meter Horiba F8-L).

\section{Hasil dan Pembahasan}

Hasil penelitian menunjukkan bahwa populasi mikroba terus meningkat dari awal perlakuan hingga akhir minggu ke-3. Peningkatan populasi yang tajam terjadi pada minggu ke-1 pada penggunaan Bacillus U41 dan kultur campuran. Peningkatan populasi yang tajam pada U44 berlangsung pada minggu ke-2. Pada akhir penelitian (minggu ke-3), peningkatan populasi mikroba paling besar terjadi pada perlakuan inokulasi campuran Bacillus U41 dan U44, hal ini menunjukkan bahwa kerja ke dua jasad tersebut bersifat sinergis baik antara keduanya maupun dengan jasad endogen substrat tersebut. Populasi mikroba pada kontrol terus meningkat tetapi tanpa ada lonjakan pertumbuhan populasi. Pada lingkungan baru mikroba akan mengalami fase adaptasi sebelum dapat tumbuh dengan baik. Masa adaptasi antara anggota spesies satu dengan lainnya berbeda tergantung kemampuan masing-masing strain anggota spesies dalam menanggapi lingkungannya (Atlas \& Bartha, 1987). Peningkatan populasi mikroba endogen tampaknya distimulasi oleh pemberian urea 0,25\% (Tabel 1). Peningkatan tersebut sejalan dengan perubahan pada peubah yang lain yang menjadi indikator aktivitas mikroba pada degradasi benzena, yaitu kadar benzena, $\mathrm{pH}$, dan kadar $\mathrm{CO}_{2}$.

Kadar benzena pada semua perlakuan terus menurun dari awal penelitian hingga minggu ke-3. Penurunan paling tajam terjadi pada minggu ke-1, misalnya pada perlakuan menggunakan Bacillus U44 yang menunjukkan penurunan benzena dari $245,57 \mathrm{ppm}$ menjadi 62,83 ppm $(74,42 \%)$ dan pada kontrol 121,80 ppm $(50,40 \%)$. Meskipun pada dalam minggu pertama kinerja Bacillus U44 merupakan yang terbaik, tetapi pada akhir penelitian (minggu 
ke-3) penurunan kadar benzena terbaik diperoleh pada penggunaan kultur campuran, dengan sisa benzena sebesar 14,86 ppm atau menurun 93,95\%. Pada penambahan Bacillus U44, sisa benzena sebesar 15,66 ppm (93,62\%), U41 20,02 ppm $(91,85 \%)$, dan kontrol 31,75ppm (87,07\%).

Data pada Tabel 2, menunjukkan bahwa penambahan nutrien berupa $\mathrm{N}$ (urea), mampu meningkatkan laju degradasi benzena oleh mikroba endogen. Bioaugmentasi Bacillus U41 dan U44 atau campurannya terbukti dapat meningkatkan laju biodegradasi sekitar 5-7\%. Data pada Tabel 2, merupakan bukti bahwa kerja sinergistik antara beragam mikroba, dalam hal ini mikroba endogen, isolat U41 dan U44 secara bersama-sama mampu menunjukkan hasil terbaik.

Hasil pengukuran menunjukkan nilai $\mathrm{pH}$ substrat terus menurun sejalan dengan berlangsungnya proses biodegradasi hidrokarbon. Biodegradasi hidrokarbon akan menyebabkan penguraian hidrokarbon menjadi senyawa seperti asam-asam organik, $\mathrm{H}_{2} \mathrm{O}$ dan $\mathrm{CO}_{2}$ (Madigan et al., 1997). Pembebasan asam -asam organik akan berakibat pada penurunan nilai $\mathrm{pH}$ substrat. Hingga akhir minggu ke-3, perubahan $\mathrm{pH}$ yang terjadi tidak signifikan. Penurunan nilai $\mathrm{pH}$ yang tajam hanya berlangsung pada minggu pertama.

Sebagaimana ditunjukkan Tabel 3, penurunan $\mathrm{pH}$ yang terbesar terjadi pada perlakuan kontrol yaitu dari $\mathrm{pH}$ 9,35 menjadi $\mathrm{pH} 7,54-7,83$. Diduga penurunan $\mathrm{pH}$ ini terjadi karena akumulasi produk antara yang bersifat asam. Berdasarkan data jumlah mikroba (Tabel 1), degradasi benzena (Tabel 2) dan kadar $\mathrm{CO}_{2}$ (Tabel 4) menunjukkan bahwa laju biodegradasi pada kontrol relatif paling lambat dibandingkan perlakuan lainnya. Hal ini mungkin merupakan indikasi bahwa bioaugmentasi Bacillus U41, U44, dan campurannya mempercepat biodegradasi hidrokarbon serta transformasi ke senyawa lanjut berupa $\mathrm{CO}_{2}$ dan $\mathrm{H}_{2} \mathrm{O}$ sehingga tidak terjadi akumulasi produk antara berupa senyawa-senyawa bersifat asam.

Menurut Said dan Fauzi (1996), penurunan $\mathrm{pH}$ tersebut dapat pula sebagai akibat sumber $\mathrm{N}$ yang digunakan. Nilai $\mathrm{pH}$ lingkungan akan cenderung menurun manakala sumber $\mathrm{N}$ yang digunakan adalah amonia atau urea $\left(\mathrm{CO}\left[\mathrm{NH}_{2}\right]_{2}\right)$. Amonia pada larutan di bawah pH 9 berada dalam bentuk $\mathrm{NH}^{4+}$. Mikroba selanjutnya akan mengikatnya sebagai $\mathrm{R}-\mathrm{NH}^{3+}$. Pada proses tersebut sebuah ion $\mathrm{H}^{+}$ akan tetap tinggal di lingkungan, sehingga $\mathrm{pH}$ akan turun.

Aktivitas pemecahan hidrokarbon termasuk benzena, pada akhirnya akan menghasilkan produk akhir berupa karbon-dioksida $\left(\mathrm{CO}_{2}\right)$ dan air $\left(\mathrm{H}_{2} \mathrm{O}\right)$. Berdasarkan hal tersebut, peningkatan kadar karbon-dioksida merupakan indikasi peningkatan aktivitas biodegradasi.

Tabel 4, menunjukkan terjadinya peningkatan karbon-dioksida sejak awal penelitian hingga akhir minggu ke-3. Karbondioksida merupakan produk akhir penguraian hidrokarbon dan dengan segera akan dibebaskan ke udara. Data pada Tabel 3 menunjukkan bahwa kadar karbon-dioksida tertinggi dijumpai pada perlakuan biodegradasi dengan bioaugmentasi Bacillus strain U44.

\section{Kesimpulan}

Bioaugmentasi bakteri Bacillus strain U41 dan U44 serta campuran ke-duanya terbukti mampu meningkatkan laju biodegradasi benzena pada tanah yang tercemar hidrokarbon. Tampilan terbaik ditunjukkan oleh perlakuan berupa bioaugmentasi campuran Bacillus U41 dan U44 dengan total penurunan kadar benzena 93,95\% . 


\section{Daftar Pustaka}

Atlas, R.M. and R. Bartha. 1987. Microbial Ecology: Fundamentals and Applications. $2^{\text {nd }} \mathrm{Ed}$. The Benjamin/Cummings Publ. Co., Inc., Menlo Park.

Balba, M.T., N. Al-Awadhi and R. Al-Daher. 1998. Bioremediation of oilcontaminated soil: microbiological methods for feasibility assessment and field evaluation. Journal of Microbiological Methods 32: 155-164.

Bouwer, E.J. 1992. Bioremediation of Organic Contaminants in the Subsurface. In: Mitchell, R. (Ed.). Environmental Microbiology, pp. 287-318. John Wiley \& Sons, Inc., Publication, New York.

Capone D.G. and J.E. Bauer. 1992. Microbial Processes in Coastal Pollution. In: Mitchell, R. (Ed.). Environmental Microbiology, pp. 191-238. John Wiley \& Sons, Inc., Publication, New York.

Chen, G., K.A. Strevett and Br. A. Vanegas. 2001. Naphthalene, phenanthrene and surfactant biodegradation. Biodegradation 12: 433-442.

Grihchenkov, V.G., R.T. Townsend, T.J. McDonald, R.L. Autenrieth, J.S. Bonner and A.M. Boronin. 2000. Degradation of petroleum hydrocarbons by facultative anaerobic bacteria under aerobic and anaerobic conditions. Process Biochemistry 35: 889-896.

Irianto, A. dan M.S. Komar. 2000. Bioremediasi In Vitro Tanah tercemar Hidrokarbon Toluena dengan Penambahan Bacillus Galur Lokal. Jurnal Mikrobiologi Indonesia Vol. 3 (2): 4347.
Joetono, Judoro, S. Kabirun, Suhadi dan Soesanto. 1980. Pedoman Praktikum Mikrobiologi Umum. Yogyakarta: Fakultas Pertanian UGM. Yogyakarta.

Madigan, M.T., J.M. Martinko and J. Parker. 1997. Brock's Biology of Microorganims. $8^{\text {th }}$ Ed. Englewood Cliffs. Prentice Hall.

Noegrohati, S. 1983. Teknik dan Uji Cemaran Pangan. Chromatografi Gas. PAU Pangan dan Gizi UGM, Yogyakarta

Pichinoty, F., J.B. Waterbury, M. Mandel and J. Asselineau. 1986. Bacillus gordonae sp. nov., Une nouvelle espèce appartenantt au second groupe morphologique dégradant divers compose aromatiques. Ann. Inst. Pasteur 137 A: 65-78.

Sabarni, N. 1995. Kemampuan Pseudomonas fluorescens FNCC 0070 dalam Biodegradasi Toluena dengan Penambahan Urea sebagai Sumber Nitrogen. Skripsi. Fakultas Biologi UNSOED, Purwokerto.

Said, E.G. and A.M. Fauzi. 1996. Bioremediasi dengan Mikroorganisme. Prosiding Pelatihan Peranan Bioremediasi dalam Pengolahan Lingkungan. LIPI, Cibinong.

Sharpley, J.M. 1966. Elementary of Petroleum Microbiology. McGraw-Hill Book Co. Hudson.

Zarilla, K.A. and J.J. Perry. 1987. Bacillus thermoleovorans, sp. nov., a species of obligately thermophilic hydrocarbon utilizing endosporeforming bacteria. Systematic and Applied Microbiology 9: 247-255 
Agus Irianto, et al.

Tabel 1. Hasil penghitungan jumlah mikroba dengan metode TPC (Total Plate Count)

\begin{tabular}{llcccc}
\hline \multirow{2}{*}{ No. } & \multirow{2}{*}{ Perlakuan } & \multicolumn{4}{c}{ Jumlah populasi (CFU/g ) } \\
\cline { 3 - 5 } & & Awal & Akhir Minggu I & Akhir Minggu II & Akhir Minggu III \\
\hline \hline 1. & Kontrol & $0,067 \times 10^{8}$ & $1,5 \times 10^{8}$ & $1,5 \times 10^{8}$ & $5,9 \times 10^{8}$ \\
2. & Penambahan U41 & $0,12 \times 10^{8}$ & $3,1 \times 10^{8}$ & $9,9 \times 10^{8}$ & $18 \times 10^{8}$ \\
3. & Penambahan U44 & $0,12 \times 10^{8}$ & $1,9 \times 10^{8}$ & $4,1 \times 10^{8}$ & $19 \times 10^{8}$ \\
4. & Penambahan U41 \& U44 & $0,12 \times 10^{8}$ & $1,9 \times 10^{8}$ & $11 \times 10^{8}$ & $24 \times 10^{8}$ \\
\hline
\end{tabular}

Tabel 2. Kadar benzena sisa selama proses biodegradasi

\begin{tabular}{|c|c|c|c|c|c|}
\hline \multirow{2}{*}{ No. } & \multirow{2}{*}{ Perlakuan } & \multicolumn{4}{|c|}{ Kadar benzena (ppm) } \\
\hline & & Awal & Akhir Minggu I & Akhir Minggu II & Akhir Minggu III \\
\hline 1. & Kontrol & 245,57 & 121,80 & 80,99 & 31,37 \\
\hline 2. & Penambahan U41 & 245,57 & 90,09 & 41,90 & 20,02 \\
\hline 3. & Penambahan U44 & 245,57 & 62,83 & 29,57 & 15,66 \\
\hline 4. & Penambahan U41 \& U44 & 245,57 & 75,95 & 26,96 & 14,86 \\
\hline
\end{tabular}

Tabel 3. Perubahan nilai pH selama penelitian

\begin{tabular}{|c|c|c|c|c|c|}
\hline \multirow{2}{*}{ No. } & \multirow{2}{*}{ Perlakuan } & \multicolumn{4}{|c|}{ Nilai kisaran pH } \\
\hline & & Awal & Akhir Minggu I & Akhir Minggu II & Akhir Minggu III \\
\hline 1. & Kontrol & 9,35 & $7,95-8,11$ & $7,79-8,01$ & $7,54-7,83$ \\
\hline 2. & Penambahan U41 & 9,35 & $8,13-8,20$ & $7,97-8,02$ & $7,81-7,99$ \\
\hline 3. & Penambahan U44 & 9,35 & $7,99-8,20$ & $7,90-8,15$ & $7,85-8,02$ \\
\hline 4. & Penambahan U41 \& U44 & 9,35 & $7,85-8,02$ & $7,85-8,01$ & $7,79-7,82$ \\
\hline
\end{tabular}

Tabel 4. Data dinamika kadar $\mathrm{CO}_{2}$ (ppm) selama proses biodegradasi

\begin{tabular}{llcccc}
\hline \multirow{2}{*}{ No. } & \multirow{2}{*}{ Perlakuan } & Awal & Akhir Minggu I & Akhir Minggu II & Akhir Minggu III \\
\cline { 3 - 6 } & & 5,28 & 7,63 & 11,73 & 27,13 \\
\hline \hline 1. & Kontrol & 5,28 & 9,53 & 14,08 & 29,3 \\
2. & Penambahan U41 & 5,28 & 8,36 & 13,2 & 33,0 \\
3. & Penambahan U44 & 5,28 & 7,9 & 13,97 & 30,95 \\
4. & Penambahan U41 \& U44 & & &
\end{tabular}


Bioaugmentasi Benzena Tanah Tercemar Hidrokarbon yang Dibiodegradasi secara in vitro 